\title{
FORMULASI SEDIAAN GEL ANTIBAKTERI EKSTRAK ETANOL 70\% DAUN BINTARO(Cerbera odollam Gaertn.) TERHADAP Staphylococcus aureus
}

Ferry Effendi ${ }^{*}$.,Herson Cahaya Himawan².,Firdhan Ausia Syahidin ${ }^{3}$

1. Program Studi Farmasi Sekolah Tinggi Teknologi Industri dan Farmasi Bogor

2. Program Studi FarmasiSekolah Tinggi Teknologi Industri dan Farmasi Bogor 3. Mahasiswa Program Studi S1 Farmasi Sekolah Tinggi Teknologi Industri dan Farmasi Bogor

Korespondensi: $\underline{\text { 3312ye@gmail.com }}$

\begin{abstract}
ABSTRAK
Ekstrak etanol 70\% daun bintaro dapat menghambat pertumbuhan bakteri Staphylococcus aureus.Ekstrak daun bintaro (Cerbera odollam Gaertn) memiliki kandungan senyawa kimia berupa flavonoid, alkaloid, dan tanin.Dalam penelitian ini dilakukan pembuatan sediaan gel ekstrak etanol $70 \%$ dari daun bintaro (Cerbera odollam Gaertn.) dan menentukan formulasi sediaan gel yang memiliki mutu fisik yang baik dan memiliki efektifitas antibakteri. Mutu fisik yang diuji meliputi homogenitas, organoleptik, viskositas, pH, daya sebar, stabilitas dan uji efektifitas antibakteri terhadap bakteri Staphylococcus aureus menggunakanmetode difusi cakram.Hasil menunjukkan sediaan gel ekstrak etanol $70 \%$ daun bintaro memiliki mutu fisik yang baik dan efektivitas antibakteri yang terbaik terdapat pada formulasi III dengan konsentrasi 5\%. Berdasarkan analisis One way Anova dengan uji lanjut Duncan setiap formulasi dengan konsentrasi yang berbeda memiliki perbedaan yang nyata dengan $\alpha=0.05$.
\end{abstract}

Kata kunci : Antibakteri, daun bintaro (Cerbera odollam Gaetrn.), difusi disk,gel, Staphylococcus aureus.

\begin{abstract}
Ethanol extract $70 \%$ of bintaro leaves could inhibit the growth of Staphylococcus aureus bacteria. Bintaro leaf extract (Cerbera odollam Gaertn) has chemical content of flavonoids, alkaloids and tannins. In this research was made preparation gel ethanol extract $70 \%$ from bintaro leaves (Cerbera odollam Gaertn.) and determine the formulation of gel preparation having good physical quality and have antibacterial effectivity. Physical quality tested such as homogeneity, organoleptic, viscosity, $\mathrm{pH}$, spreadability, stability and antibacterial effectiveness test against Staphylococcus aureus bacteria using the disk diffusion method. The results showed that ethanol extract gel of $70 \%$ of bintaro leaves had good physical quality and best antibacterial effectiveness was found in Formulation III with 5\% concentration. Based on one-way ANOVA analysis with Duncan assay, each formulation with different concentrations had a significant difference with $\alpha=0.05$.
\end{abstract}

Keywords : Antibactery, bintaro leaf(Cerbera odollam Gaetrn.), disk diffusion, gel, Staphylococcus aureus. 


\section{PENDAHULUAN}

Indonesia merupakan salah satu negara yang memiliki kekayaan akan keanekaragaman hayati berlimpah dengan jumlah keanekaragaman untuk tumbuhan yaitu sebanyak 38.000 jenis tumbuhan[1]. Terdapat beberapa jenis tumbuhan yang dipergunakan sebagai obat - obatan, tetapi sebagian besar masih merupakan tumbuhan liar. Jenis yang dapat dimanfaatkan untuk obat ini juga berbeda - beda bergantung pada bagian tumbuhan yang digunakan akar, batang, daun, bunga, buah dan biji kadang-kadang mempunyai fungsi pengobatan yang berlainan [2].

Berdasarkan perkembangannya, obat alam pada awalnya digunakan dalam bentuk aslinya, yaitu tanaman segar yang langsung digunakan oleh masyarakat untuk pengobatan penyakit. Dalam kebutuhan untuk jangka panjang membuat masyarakat berupaya mengeringkannya agar awet dalam penyimpanan. Perkembangan ilmu kefarmasian selanjutnya memungkinkan penggunaan ekstrak atau sari yang dibuat dari bahan baku kering sehingga memiliki keuntungan yaitu lebih praktis digunakan dan penderita memperoleh obat yang lebih selektif [3].

Salah satu tumbuhan yang berpotensi sebagai obat adalah tanaman bintaro (Cerbera odollam Gaertn).Bintaro adalah tanaman mangrove yang tumbuh secara luas di daerah pesisir selatan Asia Timur dan Samudera Hindia[4]. Ekstrak daun bintaro (Cerbera odollam Gaertn) memiliki golongan senyawa kimia berupa alkaloid, tanin dan kardenolid[5]. Menurut Wulandari, ekstrak etanol $70 \%$ daun bintaro dapat menghambat pertumbuhan bakteri Staphylococcus aureus[6].Hasil Konsentrasi Hambat Minimun (KHM) terhadap kedua bakteri tersebut sama, yaitu masing-masing sebesar $4 \%$.

Gel merupakan sediaan topikal yang mudah diaplikasikan pada kulit sertamemiliki penampilan fisik yang menarik dibanding sediaan topikal lainnya. Adapun penggunaan gel lebih disukai karena sediaan gel memiliki kandungan air yang bersifat mendinginkan, menyejukkan, melembabkan, mudah penggunaannya, mudah berpenestrasi pada kulit, sehingga memberikan efek penyembuhan yang lebih cepat sesuai dengan basis yang digunakan [7].

Untuk mengetahui sejauh mana efektivitas sediaan topikal berupa gel dari ekstrak etanol $70 \%$ daun bintaro (Cerbera odollam Gaertn.) dengan konsentrasi 3\%, 4\% dan 5\% maka peneliti melakukan pengujian yang meliputi uji mutu fisik berupa homogenitas, organoleptik, viskositas, $\mathrm{pH}$, daya sebar, stabilitas dan uji efektifitas antibakteri terhadap bakteri Staphlococcus aureus menggunakan metode cakram.

\section{Metode}

\section{Preparasi Sampel}

Sampel yang digunakan adalah daun bintaro (Cerbera odollam Gaertn). Sampel daun bintaro segar yang berwarna hijau dibersihkan atau disortasi, kemudian dicuci dengan air mengalir hingga bersih. Sampel daun bintaro dikeringkan dengan diangin-anginkan selama 3-5 hari. Sampel dihaluskan dengan blenderserta diayak dengan pengayak ukuran 40 mesh.

\section{Penentuan Kadar Air}

Penetapan kadar Air dilakukan sesuai dengan prosedur [8]. Cawan porselin dikeringkan pada suhu $105^{\circ} \mathrm{C}$ selama 30 menit lalu dikeringkan dalam deksikator dan ditimbang. Sebanyak 2 gram sampel daun bintaro dimasukkan dalam cawan dan dipanaskan pada suhu $105^{\circ} \mathrm{C}$ sampai diperoleh bobot konstan, kemudian didinginkan dalam deksikator dan ditimbang.

Kadar air $=\frac{\text { Simplisia.Awal }- \text { Simplisia setelah dikeringkan }}{\text { Simplisia Awal }} x 100 \%$

\section{Pembuatan Ekstrak Etanol Daun Bintaro}

Serbuk simplisia daun bintaro sebanyak $500 \mathrm{~g}$ dimaserasi dengan menggunakan pelarut etanol $70 \%$ sebanyak 5 L. Serbuk simplisia direndam selama 3 hari,setiap 24 jam maserat disaring, kemudian ditambahkan lagi pelarut etanol 70\%. Hasil maserasi kemudian dipekatkan menggunakan rotary evaporator pada suhu $50^{\circ} \mathrm{C}$ sampai diperoleh ekstrak kental daun bintaro.

Rendemen ekstrak total dihitung dengan cara membagi berat ekstrak yang dihasilkan dengan berat simplisia serbuk [8]. Perhitungan rendemen ekstrak total dapat dilakukan berdasarkan persamaan berikut:

$$
\% \text { Rendemen ekstrak total }=\frac{\text { Bobot ekstrakyang diperoleh }}{\text { Bobot simplisia serbuk }} \times 100 \%
$$

\section{Uji Fitokimia [9]}

\section{a. Uji Alkaloid}

Sebanyak $500 \mathrm{mg}$ sampel (ekstrak etanol

$96 \%$, ekstrak etil asetat, dan ekstrak n- 
heksan)ditambahkan $1 \mathrm{ml}$ asam klorida $2 \mathrm{~N}$ dan $10 \mathrm{ml}$ air, panaskan di penangas air selama 2 menit, dinginkan dan saring. Kemudian dibagi menjadi 3 tabung reaksi.Pada tabung pertama dimasukkan pereaksi Mayer, hasil dinyatakan (+) jika terbentuk endapan putih.Pada tabung kedua dimasukkan perekasi Dragendorff, hasil dinyatakan $(+)$ bila terbentuk endapan merah jingga. Pada tabung ketiga dimasukkan pereaksi Wagner, hasil dinyatakan (+) bila terbentuk endapan coklat.

b. Uji Flavonoid

Sebanyak $500 \mathrm{mg}$ sampel (ekstrak etanol $96 \%$, ekstrak etil asetat, dan ekstrak nheksan)dilarutkan dalam $5 \mathrm{ml}$ air kemudian dipanaskan selama 5 menit setelah itu disaring. Filtrat ditambahkan serbuk magnesium serta $\mathrm{HCl}$ :etanol (1:1) dan amil alkohol. Hasil dinyatakan positif bila terbentuk endapan warna jingga hingga merah ungu.

c. Uji Saponin

Sebanyak $500 \mathrm{mg}$ sampel (ekstrak etanol $96 \%$, ekstrak etil asetat, dan ekstrak nheksan)ditambahkan $5 \mathrm{ml}$ akuades dalam tabung reaksi. Dikocok kuat-kuat, adanya saponin ditandai dengan terbentuk busa yang stabil.

d. Uji Tanin

Sebanyak $500 \mathrm{mg}$ sampel (ekstrak etanol $96 \%$, ekstrak etil asetat, dan ekstrak nheksan)direbus dengan $10 \mathrm{ml}$ akuades dalam tabung reaksi selama 5 menit, kemudian disaring. Filtrat ditetesi $\mathrm{FeCl}_{3}$ 1\%.Uji positif ditandai dengan munculnya warna hijau kecoklatan atau biru kehitaman.

e. Uji Steroid

Sebanyak $500 \mathrm{mg}$ sampel (ekstrak etanol 96\%, ekstrak etil asetat, dan ekstrak n-heksan) ditambahkan etanol kemudian dipanaskan selama 2 menit. Ekstrakdisaring dalam keadaan panas kemudian filtrat diuapkan di waterbath sampai kering.Setelah kering ditambahkan $1 \mathrm{ml}$ dietil eter kemudian dihomogenkan selanjutnya ditambahkan 1 tetes $\mathrm{H} 2 \mathrm{SO} 4$ pekat dan 1 tetes $\mathrm{CH} 3 \mathrm{COOH}$ anhidrat.Uji positif ditandai dengan munculnya warna hijau atau biru.

\section{Formulasi Sediaan Gel}

Bahan uji pada penelitian ini adalah menggunakan ekstrak daun bintaro (Cerbera odollam Gaetrn.) yang diformulasikan kedalam sediaan topikal berupa gel dengan konsentrasi ekstrak daun bintaro 3, 4, dan 5\%.

Tabel 1. Formulasi gel ekstrak daun bintaro [10]

\begin{tabular}{|c|c|c|c|c|c|}
\hline Komposisi & $\begin{array}{c}\mathrm{F} 1 \\
(\mathrm{~g})\end{array}$ & $\begin{array}{c}\mathrm{F} 2 \\
(\mathrm{~g})\end{array}$ & $\begin{array}{c}\mathrm{F} 3 \\
(\mathrm{~g})\end{array}$ & $\begin{array}{c}\text { Kontrol } \\
\text { negatif } \\
(\mathrm{g})\end{array}$ & $\begin{array}{c}\text { Kontrol } \\
\text { positif } \\
(\mathrm{g})\end{array}$ \\
\hline $\begin{array}{c}\text { Ekstrak daun } \\
\text { bintaro }\end{array}$ & 1,5 & 2 & 2,5 & - & - \\
\hline Na-CMC & 2,5 & 2,5 & 2,5 & 2,5 & - \\
\hline Gliserin & 5 & 5 & 5 & 5 & - \\
\hline Propilenglikol & 2,5 & 2,5 & 2,5 & 2,5 & - \\
\hline Akuades & $\mathrm{ad}$ & $\mathrm{ad}$ & $\mathrm{ad}$ & $\mathrm{ad} 50$ & - \\
\hline 50 & 50 & 50 & & \\
\hline $\begin{array}{c}\text { Gel } \\
\text { Bioplacenton }\end{array}$ & - & - & - & - & 0,5 \\
\hline
\end{tabular}

\section{Pembuatan Sediaan Gel}

$\mathrm{Na}-\mathrm{CMC}$ ditambahkan akuades panas secukupnya dan dibiarkan hingga mengembang kemudian dilakukan pengadukan secara perlahan, ditambahkan masing-masing ekstrak yang telah ditentukan konsentrasinya kemudian dimasukan gliserin, propilenglikol dan sisa akuades sambil diaduk perlahan sampai terbentuk gel.

\section{Evaluasi Sediaan Gel}

\section{a. Uji Penampilan Fisik (Organoleptik)}

Uji penampilan fisik (organoleptik) sediaan gel dengan melihat homogenitas gel, bau dan warna sediaan yang telah dibuat[11].

\section{b. Uji Homogenitas}

Uji homogenitas dilakukan untuk melihat apakah sediaan yang telah dibuat homogen atau tidak. Caranya, gel dioleskan pada kaca transparan dimana sediaan diambil 3 bagian yaitu atas, tengah dan bawah. Homogenitas ditunjukan dengan tidak adanya butiran kasar [11]

\section{c. Uji pH}

Uji $\mathrm{pH}$ dilakukan untuk melihat tingkat keasaman sediaan gel untuk menjamin sediaan gel tidak menyebabkan iritasi pada kulit. $\mathrm{pH}$ sediaan gel diukur dengan menggunakan $\mathrm{pH}$ stick universal. $\mathrm{pH}$ sediaan yang memenuhi kriteria $\mathrm{pH}$ kulit yaitu dalam range 4,5-6,5 [12].

\section{d. Viskositas}

Pengukuran viskositas dilakukan dengan menggunakan alat viskometer Brookfield. Cara pengujian, yaitu sediaan gel dimasukkan ke dalam wadah berupa gelas piala $100 \mathrm{ml}$, spindel 
yang sesuai diturunkan hingga batas spindel tercelup ke dalam gel, kemudian motor dan spindel nomer 3 dinyalakan. Angka viskositas yang ditunjukkan oleh jarum merah dicatat, kemudian dikalikan dengan suatu faktor yang dapat dilihat pada tabel yang terdapat pada brosur alat [13]

\section{e. Daya Sebar}

Uji daya sebar dilakukan untuk menjamin pemerataan gel saat diaplikasikan pada kulit dilakukan segera setelah gel dibuat. Gel ditimbang sebanyak $0,5 \mathrm{~g}$ kemudiaan diletakkan ditengah kaca bulat lain atau bahan transparan lain dan pemberat sehingga berat kaca bulat dan pemberat $150 \mathrm{~g}$, didiamkan 1 menit, kemudian dicatat diameter penyebarannya. Daya sebar gel yang baik antara 5-7 $\mathrm{cm} \mathrm{[11].}$

\section{Uji Stabilitas}

a. Uji stabilitas pada suhu panas

Pengujian stabilitas sediaan meliputi bau, warna dan $\mathrm{pH}$ dievaluasi pada suhu tinggi yaitu $\left(40^{\circ} \mathrm{C} \pm 2^{\circ} \mathrm{C}\right)$ selama 4 minggu kemudian pengamatan dilakukan setiap 1 minggu sekali [14].

b. Uji stabilitas pada suhu kamar

Pengujian stabilitas sediaan meliputi bau, warna dan $\mathrm{pH}$ dievaluasi pada suhu kamar $\left(27^{\circ} \mathrm{C}\right.$ $\pm 2^{\circ} \mathrm{C}$ ) selama 4 minggu dengan pengamatan setiap 1 minggu sekali [14].

\section{Efektifitas Antibakteri Pembuatan Media}

Sebanyak 2,8 gram nutrient agar (NA) ditimbang dan dimasukkan ke dalam Erlenmeyer. Ditambahkan $100 \mathrm{~mL}$ akuades. Dipanaskan di atas hot plate hingga mendidih sambil diaduk dengan magnetic stirer sampai homogen, kemudian larutan NA dituangkedalam tabung reaksi ditutup menggunakan kapas, sterilkan menggunakan autoklaf dengan posisi miring selama 15 menit dengan suhu $121^{\circ} \mathrm{C}$.

\section{Penyiapan Media dan Inokulasi Bakteri}

Diambil satu ose isolat Staphyloccocus aureus dengan menggunakan ujung ose steril. Isolat kemudian digoreskan secara zig - zag pada media NA miring, dioleskan secara merata. Media dan inokulum kemudian diinkubasi pada suhu $37^{\circ} \mathrm{C}$ selama 24 jam.

\section{Pembuatan Suspensi Bakteri}

Nutrient Broth(NB) sebanyak 2,8 g diambil dan dilarutkan dalam $100 \mathrm{ml}$ akuades kemudian disterilkan menggunakan autoklaf dengan suhu $121^{\circ} \mathrm{C}$ selama 15 menit. Kultur bakteri Staphylococcus aureus diambil dari media agar miring dengan cara digores secukupnya menggunakan ose secara aseptis, setelah itu masukan jarum ose ke dalam media cair NB diinkubasi pada suhu $37^{\circ} \mathrm{C}$ selama 1 x 24 jam.

\section{Uji Efektifitas Antibakteri Secara Difusi Paper disk}

1. Media Nutrient Agar (NA) steril dan sediaan gel dengan konsentrasi 3, 4, dan 5\% beserta kontrol positif dan negatif disiapkan .

2. Media NA dituangkan kedalam cawan petri diputar dengan membentuk angka delapan untuk dihomogenkan.

3. Media Nutrient Broth (NB) yang berisi bakteri Staphylococcus aureus dimasukan kedalam cawan petri.

4. Dicelupkan kertas cakram ke dalam sediaan gel ekstrak etanol 70\% daun bintaro (Cerbera odollam Gaertn) dengan konsentrasi 3, 4, dan $5 \%$, kontrol positif dan kontrol negatif.

5. Masing- masing kertas cakram dimasukan kedalam cawan petri yang sudah ditumbuhi bakteri.

6. Cawan di inkubasikan menggunakan inkubator dengan suhu $37^{\circ} \mathrm{C}$ selama 24 jam.

7. Zona bening yang terdapat disekitararea paper diskdihitung menggunakan jangka sorong.

\section{Analisis Data}

Data aktivitas antibakteri yang diperoleh dalam penelitian ini, akan dianalisis secara statistik menggunakan metode Analisis of Variance (ANOVA) dan dilanjutkan dengan uji lanjutan Duncan.

Model rancangannya adalah :

$\mathrm{H}_{0}$ : Tidak ada hubungan antara efektifitas antibakteri dengan peningkatan ekstrak etanol $70 \%$ daun bintaro (Cerbera odollam Gaetrn.)

$\mathrm{H}_{1}$ : Ada hubungan antara efektifitas antibakteri dengan peningkatan ekstraketanol $70 \%$ daun bintaro (Cerbera odollam Gaetrn.)

Jika $\mathrm{P}$ signifikan $>0,05$ maka $\mathrm{H}_{1}$ ditolak dan $\mathrm{H}_{0}$ diterima

Jika $\mathrm{P}$ signifikan $<0,05$ maka $\mathrm{H}_{1}$ diterima dan $\mathrm{H}_{0}$ ditolak 


\section{HASIL DAN PEMBAHASAN \\ Simplisia}

Sampel yang digunakan pada penelitian ini adalah daun bintaro Simplisia daun bintaro (Cerbera odollam Gaertn.)dibuat serbuk dan diayak dengan pengayak 40 mesh.Setelah pengayakan, serbuk daun bintaro diukur kadar airnya. Penentuan kadar air berguna untuk mengetahui batasan maksimal atau kisaran kandungan air dalam bahan. Hal ini berhubungan dengan daya simpan simplisia, sehingga jika melebihi batas yang ditentukan sangat mempengaruhi waktu kadaluarsa dari simplisia tersebut. Semakin tinggi kadar air, maka semakin mudah ditumbuhi jamur dan kapang sehingga dapat menurunkan aktivitas biologi senyawa aktif selama penyimpanan. Jumlah kadar air yang baik pada daun, yaitu $\leq 10 \%$. [10]

Hasil penetapan kadar air yang diperoleh pada penelitian ini adalah 6,3\% yang artinya kadar air ekstrak daun bintaro telah memenuhi persyaratan sehingga tidak mudah ditumbuhi jamur dan kapang, serta dapat disimpan dalam waktu yang cukup lama.

\section{Hasil Ekstraksi Daun Bintaro}

Pembuatan ekstrak daun bintaro dilakukan dengan metode maserasi. Metode maserasi dipilih karena metode ini mudah dilakukan, ekonomis dan tidak merusak kandungan senyawa aktif dalam ekstrak yang tidak tahan terhadap pemanasan.Pemilihan pelarut juga termasuk faktor yang menentukan keberhasilan proses ekstraksi, prinsip ekstraksi yang sering disebut dengan istilah "like dissolve like" artinya suatu zat dapat terlarut dalam pelarut yang memiliki sifat yang sama dalam sifat kepolarannya yaitu pelarut yang bersifat polar dapat menarik senyawa yang bersifat polar. Pelarut yang digunakan pada proses maserasi ini, yaitu etanol $70 \%$ karena etanol merupakan pelarut yang efisien dalam menarik senyawa polar. Pada penelitian ini senyawa target yang terkandung dalam daun bintaro yaitu flavonoid yang bersifat polar. Serbuk simplisia daun bintaro yang diekstraksi sebanyak $500 \mathrm{~g}$ dan didapatkan ekstrak kental sebanyak 75 gsehingga hasil perhitungan rendemen ekstraknya sebesar sebesar $15 \%$.

\section{Hasil fitokimia Ekstrak Etanol Daun Bintaro \\ Uji fitokimia bertujuan untuk} menentukan golongan senyawa aktif yang terdapat pada ekstrak tanaman. Menurut Harbone, fitokimia merupakan suatu teknik analisa kandungan kimia di dalam tanaman[15].Secara umum kandungan kimia dalam tanaman dapat dikelompokan ke dalam senyawa alkaloid, flavonoid, saponin dan tanin.Untuk mengidentifikasi senyawa- senyawa tersebut yang terdapat pada tanaman dilakukan berdasarkan endapan dan warna yang ditimbulkan dengan menggunakan pereaksipereaksi yang spesifik dan khusus.

Tabel 2.Hasil Uji Fitokimia Ekstrak Etanol 70\%Daun Bintaro (Cerbera odollam Gaertn.)

\begin{tabular}{|c|c|c|}
\hline Pengujian & Hasil & Simpulan \\
\hline $\begin{array}{c}\text { Alkaloid } \\
\text { Pereaksi Mayer } \\
\text { PereaksiWagner } \\
\text { Pereaksi Dragendroff }\end{array}$ & $\begin{array}{c}\text { Terdapat endapan putih } \\
\text { Terdapat endapan kuning } \\
\text { kecoklatan } \\
\text { Terdapat endapan kuning }\end{array}$ & + \\
\hline Flavonoid & $\begin{array}{c}\text { Terdapat lapisan kuning pada } \\
\text { lapisan amil alkohol }\end{array}$ & - \\
\hline Saponin & Tidak terdapat buih & + \\
\hline Tanin & Terjadi warna hijau kehitaman & + \\
\hline Terpenoid & Terdapat warna merah & + \\
\hline
\end{tabular}

Keterangan : $\quad(+)$ hasil menunjukan positif

(- ) hasil menunjukan negatiif 
Uji Organoleptik Sediaan Gel Ekstrak Etanol 70\% Daun Bintaro (Cerbera Odollam Gaetrn.)

Pengujian organoleptik sediaan gel ekstrak daun bintaro dilakukan dengan mengamati sediaan gel berdasarkan bentuk, warna dan bau.Gel ekstrak daun bintaro memberikan bau yang khas dari daun bintaro dan bentuk sediaan gel dalam bentuk semisolid. Warna sediaan gel ini coklat yang merupakan dasar dari warna daun bintaro.Gel dengan konsentrasi 3\%memiliki warna coklat muda, karena sediaan gel tersebut mengandung ekstrak yang tidak terlalu banyak, sehingga masih bercampur dengan basis gel.Gel dengan konsentrasi $4 \%$ berwarna coklat, sedangkan gel dengan konsentrasi 5\% memiliki warna coklat tua karena kandungan ekstraknya banyak.

Tabel 3. Hasil Uji Organoleptik Gel Ekstrak Daun Bintaro

\begin{tabular}{|c|c|c|c|}
\hline Sediaan & Bau & Warna & Bentuk \\
\hline $\begin{array}{c}\text { Kontrol Positif } \\
\text { Formula I }\end{array}$ & $\begin{array}{c}\text { Khas Basis } \\
\text { Khas Ekstrak }\end{array}$ & $\begin{array}{c}\text { Bening } \\
\text { Coklat Muda }\end{array}$ & $\begin{array}{c}\text { Semisolid } \\
\text { Semisolid }\end{array}$ \\
\hline Formula II & Khas Ekstrak & Coklat & Semisolid \\
\hline Formula III & Khas Ekstrak & Coklat Tua & Semisolid \\
\hline
\end{tabular}

\section{UjiHomogenitas}

Tabel 4.Hasil Uji Homogenitas Gel Ekstrak

Daun Bintaro

\begin{tabular}{|c|c|}
\hline Jenis Gel & Homogenitas \\
\hline Kontrol & $\begin{array}{c}\text { Homogen dan } \\
\text { tidak ada partikel }\end{array}$ \\
\hline Formula I & $\begin{array}{c}\text { Homogen dan } \\
\text { tidak ada partikel }\end{array}$ \\
\hline Formula II & $\begin{array}{c}\text { Homogen dan } \\
\text { tidak ada partikel }\end{array}$ \\
\hline Formula III & $\begin{array}{c}\text { Homogen dan } \\
\text { tidak ada partikel }\end{array}$ \\
\hline
\end{tabular}

\section{Uji PH}

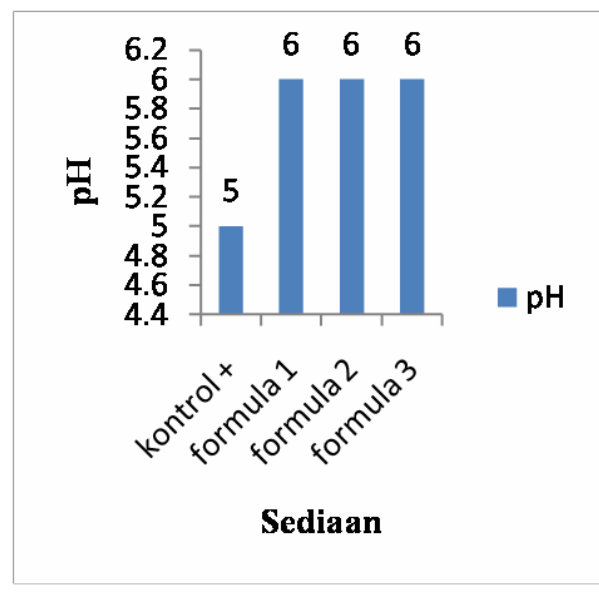

Uji Homogenitas sediaan gel yang dilakukan memberikan hasil yang homogen serta tidak adanya gumpalan atau butiran kasar pada sediaan gel antibakteri ekstrak $70 \%$ etanol daun bintaro (Cerbera Odollam Gaetrn.).Sediaan gel yang homogen mengindikasikan bahwa bahan -bahan atau komposisi yang digunakan tercampur secara baik dan merata.

\section{Gambar1. Hasil Uji pH Sediaan Gel Ekstrak Etanol 70\% Daun Bintaro (Cerbera odollam Gaetrn.)}

Uji pH yang dilakukan pada setiap sediaan gel daun bintaro diperoleh nilai yang relative sama antar gel yang diberi konsentrasi ekstrak, namun berbeda dengan kontrol. $\mathrm{pH}$ kontrol yaitu 5, sedangkan untuk $\mathrm{pH}$ sediaan yang diberi ekstrak memiliki nilai $\mathrm{pH}$ 6. Pengujian dilakukan dengan menggunakan kertas $\mathrm{pH}$ stickuniversal dengan 


\section{9|Ferry Effendi et al. ( Formulasi Sediaan Gel ...)}

cara melihat warna indikator pada kertas yang sudah dicelupkan kedalam sediaan. Sediaan gel yang dibuat Hasil pengujian $\mathrm{pH}$ yang dilakukan pada sediaan gel memenuhi persyaratan yang sesuai dengan $\mathrm{pH}$ kulit yaitu $4,5-6,5$ sehingga aman untuk digunakan, karena $\mathrm{pH}$ yang terlalu asam dapat menyebabkan iritasi kulit sedangkan $\mathrm{pH}$ yang terlalu basa dapat menyebabkan kulit kering dan bersisik.

\section{Uji Viskositas}

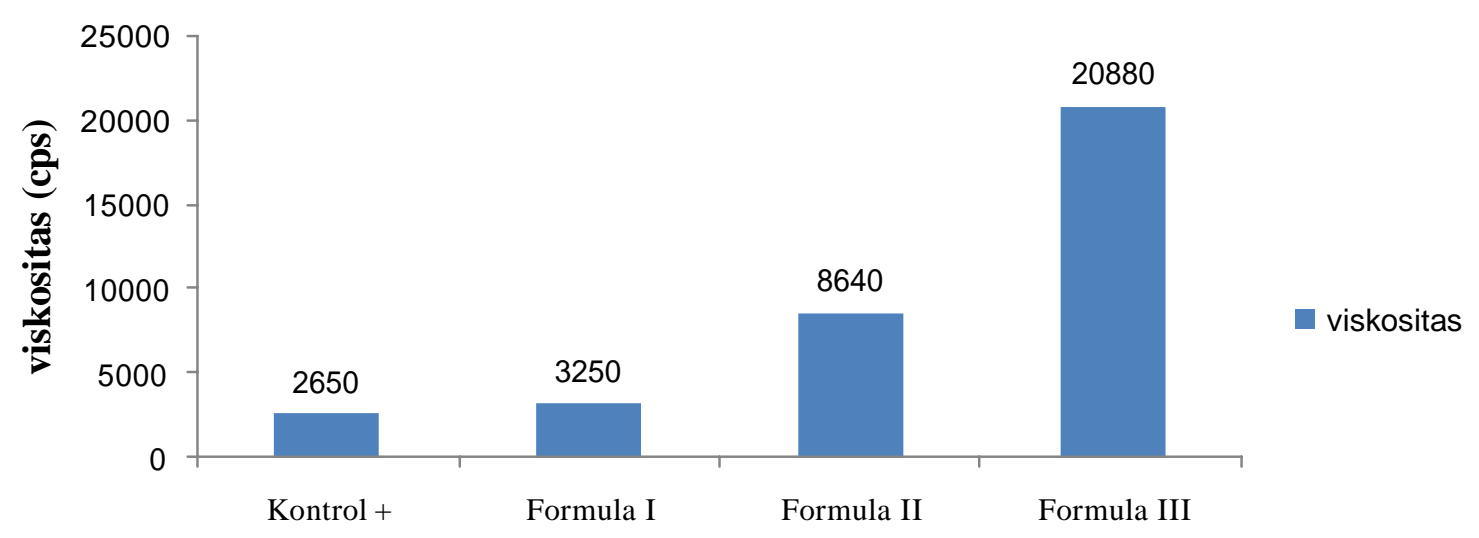

\section{Sediaan}

\section{Gambar 1 Hasil Uji Viskositas Sediaan Gel Ekstrak Etanol 70\% Daun Bintaro (Cerbera odollam Gaetrn.)}

Viskositas adalah sifat yang menentukan daya tahannya terhadap gaya geser (Karyono, 2008). Hasil uji viskositas pada sediaan gel ekstrak etanol $70 \%$ daun bintaro (Cerbera odollam Gaetrn) yang memiliki viskositas tertinggi yaitu pada Formula III dengan nilai viskositas yaitu $20.880 \mathrm{cps}$, kemudian formula II yaitu 8.640 cps, formula I yaitu $3.250 \mathrm{cps}$ dan kontrol yaitu $2.650 \mathrm{cps}$, hal ini menunjukan penambahan konsentrasi ekstrakdapat mempengaruhi viskositas dalam sediaan. Menurut Grag A. et al nilai viskositas sediaan yang baik yaitu 2000 4000 cps, artinya sediaan kontrol dan formula I memenuhi kriteria sebagai sediaan yang baik. [16].

\section{Uji Daya Sebar}

Uji daya sebar yang dilakukan dengan cara meletakan gel diatas plat kaca, kaca lainnya diletakkan diatasnya dan diberi beban sampai 100 gr selama 1 menit kemudian dihitung diameternya. Hasil uji daya sebar bertujuan untuk mengetahui kemampuan gel menyebar pada kulit. Sediaan yang nyaman digunakan memiliki daya sebar antara 5 sampai $7 \mathrm{~cm}[16]$.
Tabel 5 Hasil Uji Daya Sebar Sediaan Gel Ekstrak Daun Bintaro

\begin{tabular}{|c|c|}
\hline Sediaan & Daya Sebar $\left(\mathrm{cm}^{2}\right)$ \\
\hline Kontrol + & 8,03 \\
\hline Formula I & 7,06 \\
\hline Formula II & 5,72 \\
\hline Formula III & 5,14 \\
\hline
\end{tabular}

Hasil pengujian daya sebar gel menggunakan basis Na-CMC dan dengan menggunakan ekstrak etanol $70 \%$ daun bintaro memenuhi kriteria daya sebar untuk sediaan gel. Pada formula sediaan kontrol didapatkan nilai daya sebar $8,03 \mathrm{~cm}^{2}$ sedangkan untuk formula dengan penambahan ekstrak terjadi penurunan daya sebar yaitu $7,06 \mathrm{~cm}^{2}, 5,72 \mathrm{~cm}^{2}$ dan 5,14 $\mathrm{cm}^{2}$.Penambahan ekstrak mempengaruhi viskositas sehingga daya sebar terhadap sediaan menurun. 
50|Ferry Effendi et al. ( Formulasi Sediaan Gel ...)

Tabel 6. Hasil Uji Satabilitas Pada

Suhu Panas

\begin{tabular}{|c|c|c|c|}
\hline Minggu & Sediaan & Warna & $\mathrm{Bau}$ \\
\hline \multirow{4}{*}{1} & Kontrol + & Bening & $\begin{array}{l}\text { Khas } \mathrm{Na} \\
\text { CMC }\end{array}$ \\
\hline & $3 \%$ & $\begin{array}{l}\text { Coklat } \\
\text { Muda }\end{array}$ & $\begin{array}{l}\text { Khas } \\
\text { Ekstrak }\end{array}$ \\
\hline & $4 \%$ & Coklat & $\begin{array}{l}\text { Khas } \\
\text { Ekstrak }\end{array}$ \\
\hline & $5 \%$ & Coklat Tua & $\begin{array}{l}\text { Khas } \\
\text { Ekstrak }\end{array}$ \\
\hline \multirow{4}{*}{2} & Kontrol + & Bening & $\begin{array}{l}\text { Khas } \\
\text { Basis }\end{array}$ \\
\hline & $3 \%$ & $\begin{array}{l}\text { Coklat } \\
\text { Muda }\end{array}$ & $\begin{array}{l}\text { Khas } \\
\text { Ekstrak }\end{array}$ \\
\hline & $4 \%$ & Coklat & $\begin{array}{l}\text { Khas } \\
\text { Ekstrak }\end{array}$ \\
\hline & $5 \%$ & Coklat Tua & $\begin{array}{l}\text { Khas } \\
\text { Ekstrak }\end{array}$ \\
\hline \multirow{4}{*}{3} & Kontrol + & Bening & $\begin{array}{l}\text { Khas } \\
\text { Basis }\end{array}$ \\
\hline & $3 \%$ & $\begin{array}{l}\text { Coklat } \\
\text { Muda }\end{array}$ & $\begin{array}{l}\text { Khas } \\
\text { Ekstrak }\end{array}$ \\
\hline & $4 \%$ & Coklat & $\begin{array}{l}\text { Khas } \\
\text { Ekstrak }\end{array}$ \\
\hline & $5 \%$ & Coklat Tua & $\begin{array}{l}\text { Khas } \\
\text { Ekstrak }\end{array}$ \\
\hline \multirow{4}{*}{4} & Kontrol + & Bening & $\begin{array}{l}\text { Khas } \\
\text { Basis }\end{array}$ \\
\hline & $3 \%$ & $\begin{array}{l}\text { Coklat } \\
\text { Muda }\end{array}$ & $\begin{array}{l}\text { Khas } \\
\text { Ekstrak }\end{array}$ \\
\hline & $4 \%$ & Coklat & $\begin{array}{l}\text { Khas } \\
\text { Ekstrak }\end{array}$ \\
\hline & $5 \%$ & Coklat Tua & $\begin{array}{l}\text { Khas } \\
\text { Ekstrak }\end{array}$ \\
\hline
\end{tabular}

Uji Stabilitas

Hasil organoleptik warna menunjukan untuk semua formulasi pada minggu ke-1 sampai minggu ke -4 tidak terjadi perubahan warna pada setiap minggunya, warna yang dihasilkan yaitu warna coklat untuk formulasi dan warna bening untuk kontrol. Kemudian untuk bau semua formulasi pada minggu ke-1 sampai minggu ke-4 tidak terjadi perubahan bau pada setiap minggunya, bau yang dihasilkan yaitu bau khas ekstrak untukformulasi dan bau Na-CMC untuk kontrol. Kestabilan fisik dapat dipengaruhi oleh faktor-faktor yang mempengaruhi kestabilan kimia seperti emulgator, suspending agent, pengawet dan bahan aktif[17].

Tabel 7.Hasil Uji Stabilitas Pada Suhu Kamar Sediaan Gel Ekstrak Etanol 70\% Daun Bintaro (Cerbera odollam Gaetrn.)

\begin{tabular}{|c|c|c|c|}
\hline Minggu & Sediaan & Warna & $\mathrm{Bau}$ \\
\hline \multirow{4}{*}{1} & Kontrol & Bening & Khas $\mathrm{Na} \mathrm{CMC}$ \\
\hline & $3 \%$ & $\begin{array}{l}\text { Coklat } \\
\text { Muda }\end{array}$ & Khas Ekstrak \\
\hline & $4 \%$ & Coklat & Khas Ekstrak \\
\hline & $5 \%$ & $\begin{array}{l}\text { Coklat } \\
\text { Tua }\end{array}$ & Khas Ekstrak \\
\hline \multirow{4}{*}{2} & Kontrol & Bening & Khas Basis \\
\hline & $3 \%$ & $\begin{array}{l}\text { Coklat } \\
\text { Muda }\end{array}$ & Khas Ekstrak \\
\hline & $4 \%$ & Coklat & Khas Ekstrak \\
\hline & $5 \%$ & $\begin{array}{l}\text { Coklat } \\
\text { Tua }\end{array}$ & Khas Ekstrak \\
\hline \multirow{4}{*}{3} & Kontrol & Bening & Khas Basis \\
\hline & $3 \%$ & $\begin{array}{l}\text { Coklat } \\
\text { Muda }\end{array}$ & Khas Ekstrak \\
\hline & $4 \%$ & Coklat & Khas Ekstrak \\
\hline & $5 \%$ & $\begin{array}{l}\text { Coklat } \\
\text { Tua }\end{array}$ & Khas Ekstrak \\
\hline \multirow{4}{*}{4} & Kontrol & Bening & Khas Basis \\
\hline & $3 \%$ & $\begin{array}{l}\text { Coklat } \\
\text { Muda }\end{array}$ & Khas Ekstrak \\
\hline & $4 \%$ & Coklat & Khas Ekstrak \\
\hline & $5 \%$ & $\begin{array}{l}\text { Coklat } \\
\text { Tua }\end{array}$ & Khas Ekstrak \\
\hline
\end{tabular}

Hasil pengujian organoleptik menunjukan pada penyimpanan suhu sedang selama 4 minggu untuk warna pada semua formulasi tidak ada perubahan warna, warna yang dihasilkan yaitu warna coklat untuk formulasi dan warna bening untuk kontrol, kemudian pada pengujian bau untuk setiap formulasi pada suhu sedang selama penyimpanan 4 minggu tidak terjadi perubahan bau, bau yang dihasilkan yaitu bau khas ekstrak.

Efektifitas Antibakteri Zona Hambat 
51|Ferry Effendi et al. ( Formulasi Sediaan Gel ... )

\section{Tabel 8.Hasil Uji Efektifitas Antibakteri Sediaan Gel Ekstrak Etanol 70\%Daun Bintaro (Cerbera odollam Gaetrn.)}

\begin{tabular}{|c|c|c|c|c|c|}
\hline \multirow[t]{2}{*}{ Formula } & \multicolumn{3}{|c|}{$\begin{array}{l}\text { Zona Hambat } \\
(\mathrm{mm})\end{array}$} & \multirow{2}{*}{$\begin{array}{l}\text { Rera } \\
\text { ta }\end{array}$} & \multirow{2}{*}{$\begin{array}{l}\text { Respo } \\
\mathrm{n} \\
\text { Hamba } \\
\tan \end{array}$} \\
\hline & $\mathrm{A}$ & B & $\mathrm{C}$ & & \\
\hline $\begin{array}{l}\text { Kontrol } \\
\text { Positif }\end{array}$ & $\begin{array}{l}23,4 \\
5\end{array}$ & $\begin{array}{l}23,2 \\
2\end{array}$ & $\begin{array}{l}22,0 \\
3\end{array}$ & $\begin{array}{l}22,9 \\
0\end{array}$ & Kuat \\
\hline Formula 1 & $\begin{array}{l}12,4 \\
7\end{array}$ & $\begin{array}{l}12,0 \\
5\end{array}$ & $\begin{array}{l}10,2 \\
7\end{array}$ & $\begin{array}{l}11,5 \\
9\end{array}$ & Lemah \\
\hline Formula 2 & $\begin{array}{l}14,0 \\
0\end{array}$ & $\begin{array}{l}13,5 \\
0\end{array}$ & $\begin{array}{l}13,4 \\
5\end{array}$ & $\begin{array}{l}13,6 \\
5\end{array}$ & Lemah \\
\hline Formula 3 & $\begin{array}{l}16,4 \\
0\end{array}$ & $\begin{array}{l}16,1 \\
2\end{array}$ & $\begin{array}{l}18.2 \\
8\end{array}$ & $\begin{array}{l}16,9 \\
3\end{array}$ & $\begin{array}{l}\text { Sedan } \\
\mathrm{g}\end{array}$ \\
\hline
\end{tabular}

Hasil penelitian menunjukan bahwa kontrol negatif tidak menunjukan aktifitas zona hambat.Hal tersebut membuktikan bahwa basis gel Na-CMC tidak berpengaruh terhadap aktifitas antibakteri, sehingga aktifitas antibakteri hanya berasal dari ekstrak bukan dari basis gel yang dipakai. Dari data diatas menunjukan bahwa daya hambat terbesar terdapat pada sediaan kontrol positif gel bioplacenton ${ }^{\circledR}$ dengan respon hambatan sebesar 22,90 mm, sedangkan pada formulasi sediaan gel ekstrak etanol $70 \%$ daun bintaro didapatkan hasil bahwa sediaan gel formula 3 dengan konsentrasi 5\% menunjukan daya hambat yang terbesar dibandingkan formulasi lainnya yaitu dengan nilai 16,93 diikuti formula 2 dengan nilai 13,65 dan Formula 1 dengan nilai 11,59. Hal ini menandakan semakin banyak konsentrasi ekstrak yang ditambahkan maka akan mempengaruhi besarnya zona hambat yang didapat dilihat dari meningkatnya zona hambat yang didapat dari konsentrasi 3, 4, dan $5 \%$.Terbentuknya zona hambat antara koloni bakteri dengan sisi terluar kertas cakramyang merupakan daerah bebas dari sel-sel bakteri. Lebar zona hambatan pertumbuhan bakteri semakin lama semakin mengalami penurunan, hal ini menunjukan efektifitas zat bakteriostatik yang dimiliki dalam ekstrak daun bintaro (Cerbera odollam Gaetrn.) juga semakin menurun.

Dari analisis data statistic anova didapatkan hasil yaitu $\mathrm{P}$ sig $0,00<0,05$ yang berarti nilai $\mathrm{P}$ sig kurang dari 0,05 dimana hasil ini menunjukan adanya hubungan antara efektifitas antibakteri dengan peningkatan ekstrak. Terdapat perbedaan yang nyata terhadap aktifitas antibakteri yaitu pada formulasi dengan konsentrasi 3, 4 dan 5\%

.Zona hambat tertinggi didapatkan pada formulasi dengan konsentrasi 5\% sedangkan zona bening terendah didapatkan oleh konsentrasi $3 \%$.

\section{SIMPULAN}

Hasil penelitian menunjukkan bahwa:

Ekstrak etanol $70 \%$ daun bintaro memiliki kandungan metabolit sekunder berupa flavonoid, alkaloid dan tanin.

Sediaan gel ekstrak etanol $70 \%$ daun bintaro memiliki mutu fisik yang baik.

Sediaan gel ekstrak etanol $70 \%$ daun bintaro pada formula III dengan konsentrasi 5\% memiliki nilai zona hambat paling tinggi terhadap bakteri Staphylococcus aureus.

\section{SARAN}

Saran dalam penelitian ini adalah sebagai berikut

Perlu dilakukan pengujian preklinis terkait sediaan gel ekstrak etanol $70 \%$ daun bintaro (Cerbera odollam Gaetrn.)

Perlu dilakukan karakteristik lebih lanjut terkait sediaan gel etanol $70 \%$ daun bintaro (Cerbera odollam Gaetrn.)

Perlu dilakukan variasi optimasi konsentrasi ekstrak

Perlu dilakukan uji stabilitas Cycling testuntuk meninjau perubahan sifat kimia dan fisik sediaan gel dalam perubahan suhu yang ekstrim.

\section{DAFTAR PUSTAKA}

[1] Supriatna, J. 2008. Melestarikan Alam Indonesia. Jakarta: Yayasan Obor Indonesia.

[2] Sastrohamidjojo. 1996. Sintesis Bahan Alam. Cetakan Pertama, Yogyakarta : Universitas Gadjah Mada.

[3] Pramono, S. 2002. Kontribusi Bahan Obat Alam Dalam Mengatasi Krisis Bahan Obat Di Indonesia. Yogyakarta : Jurnal Bahan Alam Indonesia

[4] Cheenpracha, S., Karalai, C., Rat-apa, Y., Ponglimanont, C., \& Chantrapromma, K., 2004. New Cytotoxic Cardenolide Glycoside 
from the Seeds of Cerbera manghas,

Chem. Pharm. Bull. 8:1023-1025

[5] Jannah, S. R. 2013. Aktivitas Ekstrak Etanol Daun Bintaro (cerbera odollam gaertn) Terhadap Bakteri shigella sonnie danStaphylococcuss aprophyticus Beserta Bioautografinya. Surakarta: Universitas Muhammadiyah Surakarta.

[6] Wulandari, M.A. 2014. Potensi Antibakteri dan Bioautografi Ekstrak Etanol, Daun Bintaro (cerbera odollam gaertn) Terhadap Salmonella Typhi dan Staphylococcus aureus[SKRIPSI] Surakarta: Universitas Muhammadiyah Surakarta.

[7] Ansel, H.C. 1989. Pengantar Bentuk Sediaan Farmasi, diterjemahkan oleh Farida Ibrahim Edisi 1V. Jakarta: UI-

Press

[8] [Depkes] Departemen Kesehatan 1995. Materia Medika Indonesia Jilid I-IV. Jakarta :Menteri Kesehatan Indonesia

[9] Harborne, 1996. Metode Fitokimia Penuntun Cara Modern Menganalisis Tumbuhan. Terbitan kedua. Terjemahan K. Padmawinata dan 1. Soediro. Bandung: ITB.

[10] Maswadeh, H.M., Semreen M.H., Halim A.A. 2006. In Vitro Dissolution Kinetic Study of Theophylline from Hydrophilic and Hydrophobic Matrices, Acta Poloniae Pharmaceutica and Drug Research,

Hal : $63-67$

[11] Mappa, Tiara, Eddy H.J., Kojong. N. 2013. Formulasi Gel Ekstrak Daun Sasaladahan (Peperomia pellucida (L.) H.B.K) dan Uji Efektivitasnya Terhadap Luka Bakar Pada Kelinci (Oryctolagus Cuniculus). Jurnal Ilmiah FarmasiVol 2(2): 51

[12] Tranggono dan Latifah. 2007. Buku Pegangan Ilmu Pengetahuan Kosmetik. Jakarta: Penerbit Pustaka Utama. Hal 12-22

[13] Rahmawanty., Dina2014. Formulasi Gel Menggunakan Serbuk Daging Ikan Haruan (Channa striatus)Sebagai Penyembuh Luka. hal 11 - 33.

[14] Agoes, G. \& Darijanto, S.T., 2013, Teknologi Farmasi Likuida Dan Semi Solida.Bandung: Pusat Antar Universitas Bidang Ilmu Hayati ITB.

Hal: 4-6

[15] Harbone. J. B., 1987. Metode Fitokimia.

Bandung: Penerbit ITB

[16] Grag, A.,Aggarwal, D., Garg, S., Singla, S.A. 2002. Spreading of semisolid formulation. Journal updatePharmacetical Technology, 2002:84-104.

[17] Djajadisastra, Joshita. 2004. Cosmetic Stability disampaikan pada "Seminar Setengah Hari HIKI". 8 November 2004. 